\title{
The effect of vegetation canopy on canopy storage capacity with different rainfall intensity
}

\author{
Nur Syahida A.M. ${ }^{1 *}$, and Azinoor Azida A.B. ${ }^{2}$ \\ ${ }^{1}$ Master Student, Faculty of Civil Engineering, Universiti Teknologi MARA, 41450 Shah Alam, \\ Selangor \\ ${ }^{2}$ Senior Lecturer, Faculty of Civil Engineering, Universiti Teknologi MARA, Johor Branch, Pasir \\ Gudang Campus, 81750 Masai, Johor
}

\begin{abstract}
Canopy Interception is one of the vital component in hydrological cycle and underestimating the interception process can significantly affect the water balance. A study of rainfall interception was conducted using rainfall simulator called hydrology apparatus. Three different rainfall intensities were used in this study; $90 \mathrm{~mm} / \mathrm{hr}, 140 \mathrm{~mm} / \mathrm{hr}$ and $180 \mathrm{~mm} / \mathrm{hr}$. These intensities were produced by 8 nozzles. The test were first carried out on the barren land without the existence of canopy cover. To study the effect of canopy cover on canopy storage capacity, broadleaf plant (Scindapsus Aureus) was used to cover the barren land. The differences between the amount of water discharge between these two different land covers were observed to determine the quantity of water stored in the canopy. Results indicated that Scindapsus Aureus intercepted more water at lower intensity than at higher intensity. The lowest intensity was $90 \mathrm{~mm} / \mathrm{hr}$ stored $1.6 \mathrm{~mm}$ of rainwater while $140 \mathrm{~mm} / \mathrm{hr}$ retained 0.8 $\mathrm{mm} .180 \mathrm{~mm} / \mathrm{hr}$ was the highest rainfall intensity used in this study intercepted $0.3 \mathrm{~mm}$ of total precipitation. Therefore, this study proved that rainfall intensity is one of the main factors that influence the rainfall interception process.
\end{abstract}

\section{Introduction}

Canopy interception can be described as an act of blocking the rainwater or snowflakes from direct fall to the ground by using tree, grass or shrub. Interception process is considered as a very significant process in hydrological balance because it is the second process after precipitation process. It influences all the other processes in water cycle for example, infiltration, runoff, flood generation and moisture recycling [1].

Canopy storage capacity (S) is the amount of water that can be stored in the canopy [2]. It is one of the vital parameter to the canopy interception process along with canopy cover and wet canopy evaporation [3]. Generally, canopy storage capacity is expressed in $\mathrm{mm}$. [1] state that storm intensity plays a vital role to canopy storage capacity where high intensity results to having low storage capacity. Meanwhile, small intensity results to higher storage capacity. After the canopy storage capacity has reached its limit, the water

\footnotetext{
*Corresponding author: syahidamanaf@gmail.com
} 
retained on the leaf will start to drip down [3]. Table 1 shows the canopy storage capacity by other researchers.

Direct method and indirect method is used to determine storage canopy capacity. While indirect method cost less [4] and easy to apply [5], it takes longer time to measure the capacity of storage [4]. Direct method need less period but it also needs special instrumentation, hence it costs more [4]. Rainfall intensity, duration of the storm and temporal and spatial variability of trees are few factors that influence canopy storage capacity [6]

The objective of this paper was to study the canopy storage capacity for Scindapsus Aureus. Other objective was to investigate the effect of different rainfall intensity on canopy storage capacity.

Table 1 Canopy Storage Capacity from previous researches

\begin{tabular}{|c|c|c|c|c|}
\hline Tree Species & Type of leaf & $\begin{array}{l}\text { Canopy Storage } \\
\text { Capacity, S (mm) }\end{array}$ & Location & References \\
\hline $\begin{array}{l}\text { Quercus Petraea } \\
\text { Fagus Sylvatica } \\
\text { Mixed oak-beech }\end{array}$ & $\begin{array}{l}\text { Broadleaf } \\
\text { Broadleaf } \\
\text { Broadleaf }\end{array}$ & $\begin{array}{l}0.22-0.8 \\
0.24-1.12 \\
0.53-1.17\end{array}$ & Belgium & [4] \\
\hline $\begin{array}{l}\text { Branchystegia Spiciformis } \\
\text { Hyparrhenia Filipendula }\end{array}$ & $\begin{array}{l}\text { Broadleaf } \\
\text { Needle Leaf }\end{array}$ & $\begin{array}{l}1.8 \\
1.5\end{array}$ & Zimbabwe & [1] \\
\hline Quercus Brantii & Broadleaf & $\begin{array}{l}1.56 \text { (Leaf Period) } \\
0.56 \text { (Leafless Period) }\end{array}$ & Iran & [7] \\
\hline Hevea Brasiliensis & Broadleaf & 0.11 & Malaysia & [9] \\
\hline $\begin{array}{l}\text { Juniperus Virginia } \\
\text { Tallgrass Prairie }\end{array}$ & $\begin{array}{l}\text { Needle Leaf } \\
\text { Needle Leaf }\end{array}$ & $\begin{array}{l}2.14-3.44 \\
0.27-3.86\end{array}$ & USA & {$[2]$} \\
\hline $\begin{array}{l}\text { Pinus Eldarica } \\
\text { Cupressus Arizonica }\end{array}$ & $\begin{array}{l}\text { Needle Leaf } \\
\text { Needle Leaf }\end{array}$ & $\begin{array}{l}1.31 \\
1.00\end{array}$ & Iran & [8] \\
\hline
\end{tabular}

\section{Methodology}

\subsection{Vegetation Sample}

Scindapsus Aureus Plant was chosen to obtain the canopy storage capacity using laboratory work as shown in Fig. 1. Scindapsus Aureus is a broadleaved plant where it has round, flat, heart-shaped, dark green, and plump leaves. The size of the leaves is about 3 to 4 inches for young plant. Scindapsus Aureus is also a perennial plant. It requires $15^{\circ} \mathrm{c}$ to $30^{\circ} \mathrm{c}$ to grow and a little or too much sunlight will change the color of the leaves. This plant was used for this study because it can grow outdoor as well as indoor [10]. Therefore, it is suitable to be used in laboratory.

\subsection{Soil Properties}

The type of soil used for this experiment was tested using particle size distribution test. Soil sample was weighted and dried for 24 hours. After that, it was placed on mechanical shakers for about 10 minutes to allow the soil to go through different size of sieve stack. The sieves were weighted to measure the soil retained on each pans. The initial moisture content was obtained by drying the soil for 24 hours in drying oven at $105^{\circ} \mathrm{c}$ to $110^{\circ} \mathrm{c}$ [11]. 


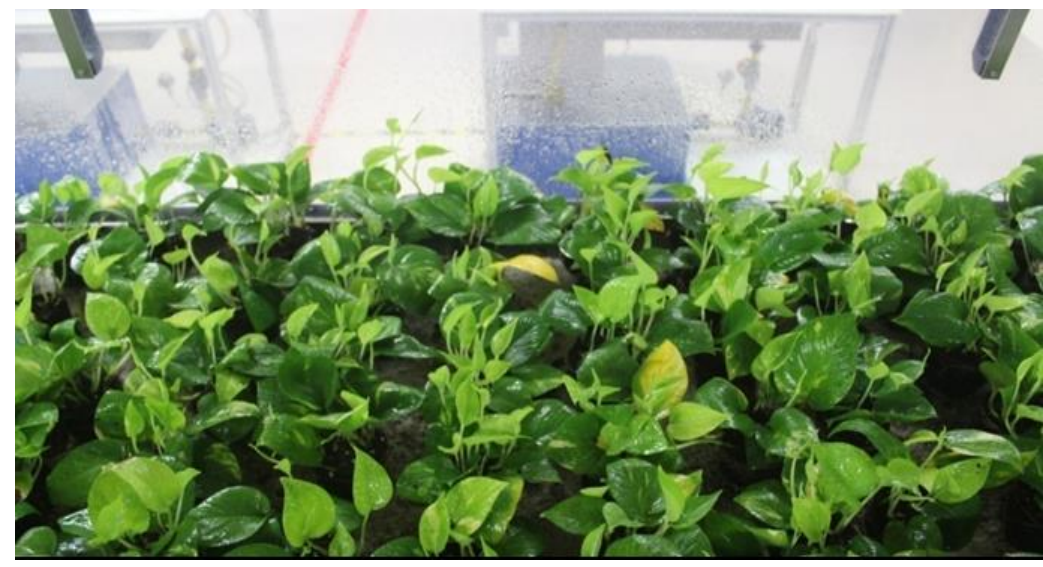

Fig. 1. Vegetation Cover (Scindapsus Aureus)

\subsection{Hydrology Apparatus}

In this study, the tests were performed using laboratory measurement. Hydrology apparatus called rainfall simulator was the main apparatus for data collection. The overall dimensions were approximately $2.4 \mathrm{~m}$ long $\times 1.0 \mathrm{~m}$ wide $\mathrm{x} 1.8 \mathrm{~m}$ high. It was operated using main electricity to drive water pump. 8 nozzles were installed to produce artificial rainfall. Adjustment of valves provided controlled the quantity of rainfall. By controlling valves, different rainfall intensities were established. The catchment area was $2 \mathrm{~m}$ long x $1 \mathrm{~m}$ wide. The catchment contained graded granular material and the thickness of soil sample was $180 \mathrm{~mm}$. A protective screen was installed around the apparatus to limit the water spray as well as to prevent wind effect. The constraining weirs at both end of tank catchment were used to measure the amount of water discharge. The apparatus also came with 20 piezometers to record the pressure of groundwater [12]. Fig. 2 shows the Kholler GHE20 Hydrology apparatus.

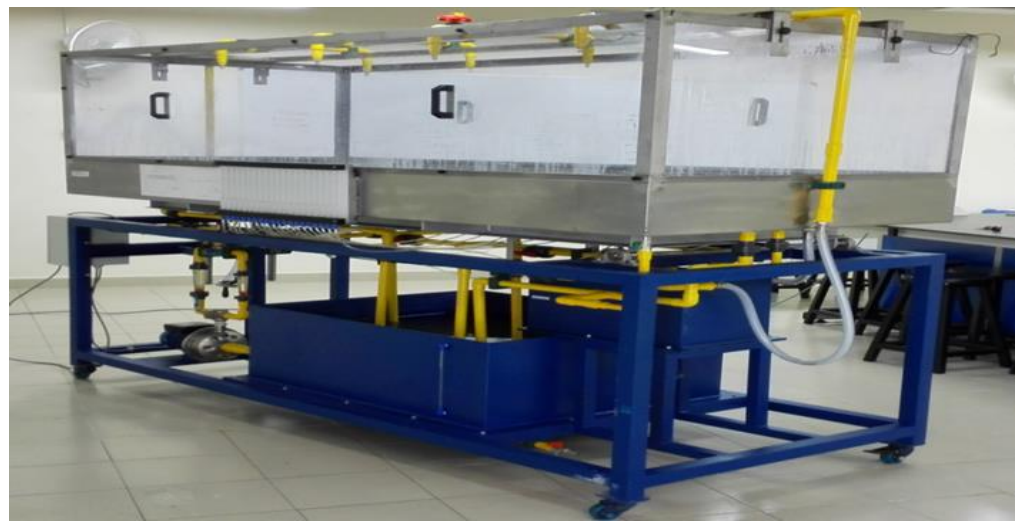

Fig. 2. Kholler GHE20 hydrology apparatus

\subsubsection{Rainfall Intensity}

Three different rainfall intensities were used in this experiment to study the effect of rainfall intensity to canopy storage capacity. The different intensities were produced by 
adjusting the valves (A and B) that had been attached to the apparatus. Valve B was opened to allow the water passed through rotameter to overhead sprinklers to produce artificial rainfall. The sprinklers were then distributed the water uniformly all over the catchment. The rainfall intensities that were generated using rainfall simulator were $90 \mathrm{~mm} / \mathrm{hr}, 140$ $\mathrm{mm} / \mathrm{hr}$ and $180 \mathrm{~mm} / \mathrm{hr}$.

\subsubsection{Time for water discharge}

After the pump circulated the water from the tank to sprinklers and produced rainfall, the rainfall felt into the catchment. The water then infiltrated into the soils. After several minutes, the catchment started to fill with water and once it reached the drainage provided in the soil, the water started to discharge through portholes at the end of catchment. The time taken for water to discharge after rainfall started was recorded using stopwatch.

\subsubsection{Water discharge}

Two portholes provided in the catchment allowed the groundwater to discharge through them. After the groundwater reached a certain level, the portholes produced the water discharge. Two small beakers were placed under the portholes to measure water discharge and the time was recorded for the water to fill the beakers. The volume of water discharge was then recorded.

\subsubsection{Canopy Storage Capacity}

General water balance equation as shown in Equation 1 was used in this study. By using this concept, the interception loss was obtained. The changes in water storage between barren land and land with canopy cover was recorded to measure the interception loss.

$$
I-O=\frac{\Delta s}{\Delta t}
$$

where ;

I = Inflow

$0=$ Outflow

$\Delta \mathrm{S}=$ Water Storage

$\Delta \mathrm{t}=$ Time

Inflow consists of precipitation process while outflow is a process interflow or water discharge. On barren land, the rainfall will either infiltrate into the soil or become runoff. By adding canopy cover, the interception process was added to the hydrology cycle. An amount of water that was intercepted by leaves was considered as interception loss. Hence, it affected the volume of interflow. Fig. 3 shows the component of hydrological balance with interception process. 


\section{Result and Discussion}

\subsection{Soil properties}

The soil used in this study was granular sand and the initial moisture content is constant throughout the test period which range between $4 \%$ to $6 \%$ because the tests were performed indoors in controlled process of precipitation and absence of wind and direct sunlight.

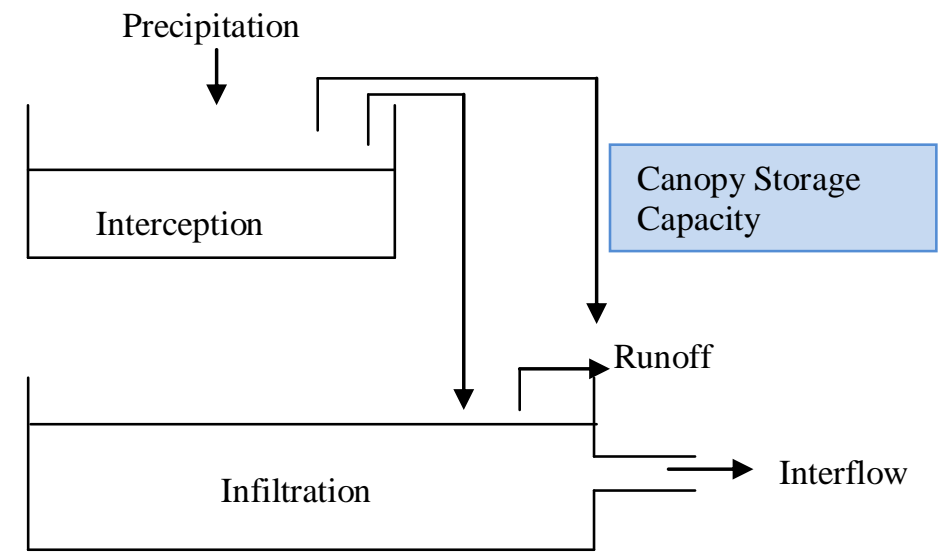

Fig. 3. Diagrammatic representation of hydrological balance

\subsection{Rainfall intensity}

Three different rainfall intensities were used in this experiment; $90 \mathrm{~mm} / \mathrm{hr}, 140 \mathrm{~mm} / \mathrm{hr}$ and $180 \mathrm{~mm} / \mathrm{hr}$. Rainfall by natural precipitation process has lower intensity compare to artificial rainfall. Most of the intensities produce by rainfall simulator are higher for example, [13] used rainfall simulator to study the canopy water storage under four intensities; 20, 60, 250 and $420 \mathrm{~mm} / \mathrm{hr}$. [14] studied the effect of vegetation and soil stability on surface runoff and soil erosion under $60 \mathrm{~mm} / \mathrm{hr}$ rainfall intensity. In addition, [15] chose $100 \mathrm{~mm} / \mathrm{hr}$ to investigate the impact of land use and cover on surface runoff.

\subsection{Time for water discharge}

This section discussed the influence of canopy interception process towards time of water discharge. The result showed that the presence of vegetation cover altered the time taken for water to start discharging. For barren land, $90 \mathrm{~mm} / \mathrm{hr}$ rainfall intensity took about 9 minutes for water to discharge after precipitation process while time for water discharge for $140 \mathrm{~mm} / \mathrm{hr}$ rainfall intensity was 7 minutes. The fastest for water to discharge was 5 minutes for $180 \mathrm{~mm} / \mathrm{hr}$.

By changing the condition of the catchment by adding Scindapsuss Aureus Plant, the results indicated that the time for water discharge was slower than the barren land. The longest time the rain water took to discharge was 18 minutes for $90 \mathrm{~mm} / \mathrm{hr}$. Rainfall intensity of $140 \mathrm{~mm} / \mathrm{hr}$ and $180 \mathrm{~mm} / \mathrm{hr}$ discharged the water at 10 minutes and 9 minutes respectively.

It can be concluded that the rainfall intensity affects the time of water discharge for both catchment conditions. Canopy cover slowed down the impact of rainfall on the soil surface causing the water to infiltrate into the soil at a slower pace [16]. The time taken for water discharge decreased when the rainfall intensity increased for both catchment cover. 
Therefore, the rainfall intensity is inversely proportional to the time of water discharge as shown in Fig. 4. There is a lack of information regarding time of water discharge. However, [17] found the delay in net precipitation peak rate about 10 minutes compared to gross precipitation peak rate. It indicates the delay of peak runoff from a storm due to interception process.

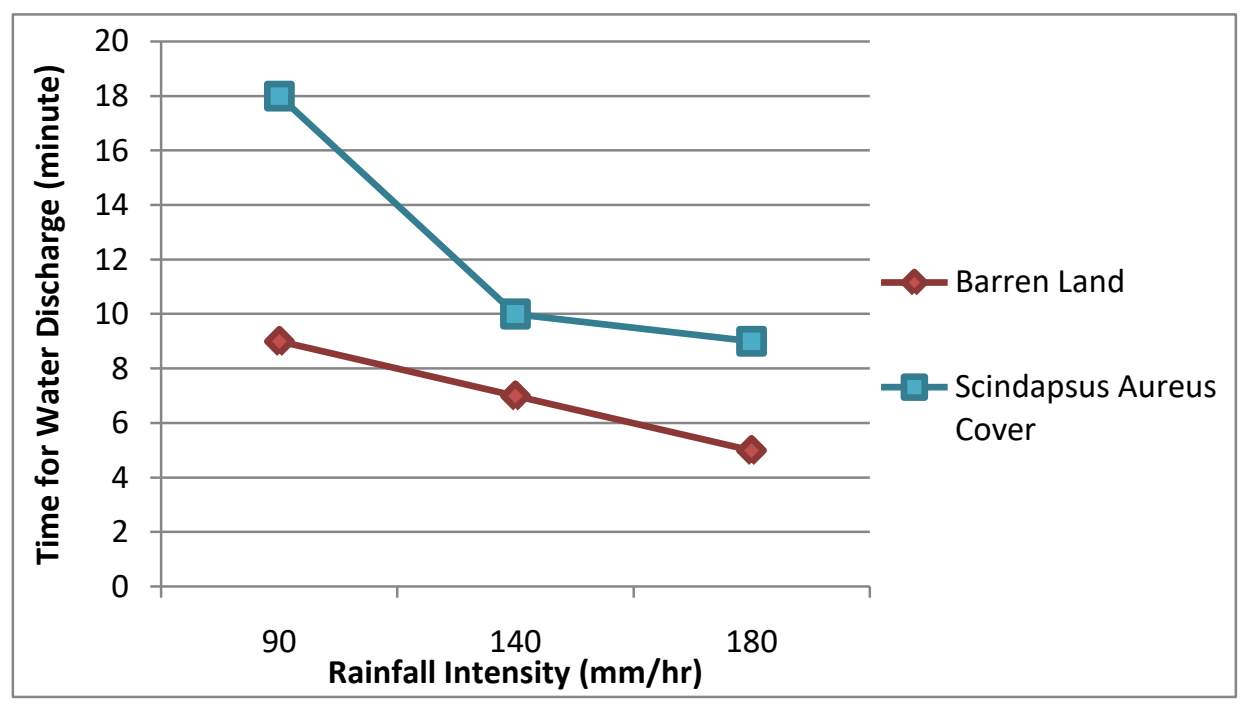

Fig. 4. Relationship between rainfall intensity and time for water discharge

\subsection{Water discharge}

The effect of rainfall intensity on water discharge also was observed. The results show in Fig. 5 indicated that water discharge is effected by different intensity and also the presence of canopy cover. For barren land, the slowest intensity which is $90 \mathrm{~mm} / \mathrm{hr}$ discharged the water at $1 \times 10^{-5} \mathrm{~m}^{3} / \mathrm{s}$. The water discharge for $140 \mathrm{~mm} / \mathrm{hr}$ intensity was $1.4 \times 10^{-5} \mathrm{~m}^{3} / \mathrm{s}$, slightly higher than $90 \mathrm{~mm} / \mathrm{hr} .180 \mathrm{~mm} / \mathrm{hr}$ rainfall intensity discharged water at rate $2 \times 10^{-5}$ $\mathrm{m}^{3} / \mathrm{s}$. This is the highest rate at barren land.

The result demonstrates that canopy cover reduces the rate of water discharge. Intensity of $90 \mathrm{~mm} / \mathrm{hr}$ produced water discharge at rate $0.2 \times 10^{-5} \mathrm{~m}^{3} / \mathrm{s}$ while $140 \mathrm{~mm} / \mathrm{hr}$ and 180 $\mathrm{mm} / \mathrm{hr}$ rainfall intensity recorded $0.7 \times 10^{-5} \mathrm{~m}^{3} / \mathrm{s}$ and $1.1 \times 10^{-5} \mathrm{~m}^{3} / \mathrm{s}$ of water discharge respectively. Rainfall intensity is directly proportional towards water discharge for both catchment condition. The higher the intensity, the higher the water discharge. However, canopy cover caused the water discharge decreases at all three level of intensities.

In addition, the amount of water loss to canopy interception also influenced the water discharge. [18] stated that the average daily runoff increases as the area of forest decreases. The growth of forest decreases the surface flow and increases the infiltration rate. Thus, land cover does affect the water discharge [19] . Furthermore, streamflow increases after clearing forest area but decreases as the forest is established [20]. [21] declared vegetation decreases runoff energy and improve soil texture.

\subsection{Canopy storage capacity}

Canopy storage capacity for Scindapsus Aureus was determined by measuring the difference between water discharge at barren land and land with canopy cover. The theory 
behind this is the different values between these two covers indicate the water lose to canopy interception. For barren soil, rain water fall straight to the ground because there is no obstacle from canopy cover. The amount of rainfall that reached the soil is the same with the total amount of rainfall produced. However, with canopy cover, some part rain water is stored on canopy surface before it started to drip down or evaporate. This part of rain water is considered as interception loss.

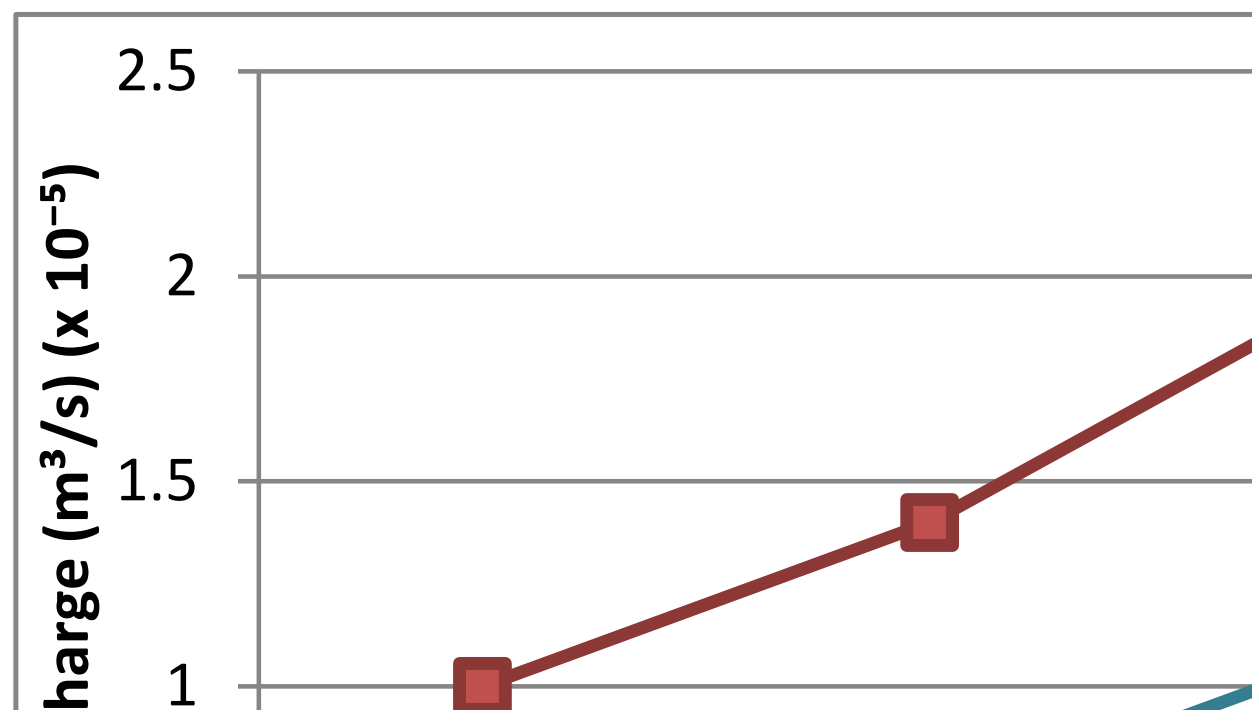

Fig. 5. Relationship between rainfall intensity and water discharge

For Scindapsus Aureus, the storage capacity at $90 \mathrm{~mm} / \mathrm{hr}$ was $1.6 \mathrm{~mm}$ which was the highest capacity between these three different intensities. For rainfall with $140 \mathrm{~mm} / \mathrm{hr}$ intensity, the interception loss recorded was $0.8 \mathrm{~mm}$ while $180 \mathrm{~mm} / \mathrm{hr}$ can only stored the water for $0.3 \mathrm{~mm}$. It is discovered that the canopy storage capacity decreased as rainfall intensities increased as shown in Fig. 6. This may be because of the high intensity impact on canopy surface causes the leaves to shake and shed the water on surface without storing it. [13] found as rainfall intensity increases, incremental storage gains decreases. However, they also stated that canopy cover generally intercepts more water at higher rainfall intensity. Canopy storage capacity in their study range between $0.05 \mathrm{~mm}$ to $1.1 \mathrm{~mm}$. The finding is contrary to this study where it is recorded that interception loss decreases as rainfall intensity decreases. However, [22] support this finding. They found that the higher the intensity, the lower the canopy storage capacity due to high impact and leaves shacking. [1] also agreed that less intensive intensity intercept more water compare to high intensity. They found that Msasa Leaf has capacity to store water about $1.8 \mathrm{~mm}$ and Thatching grass is $1.5 \mathrm{~mm}$. 


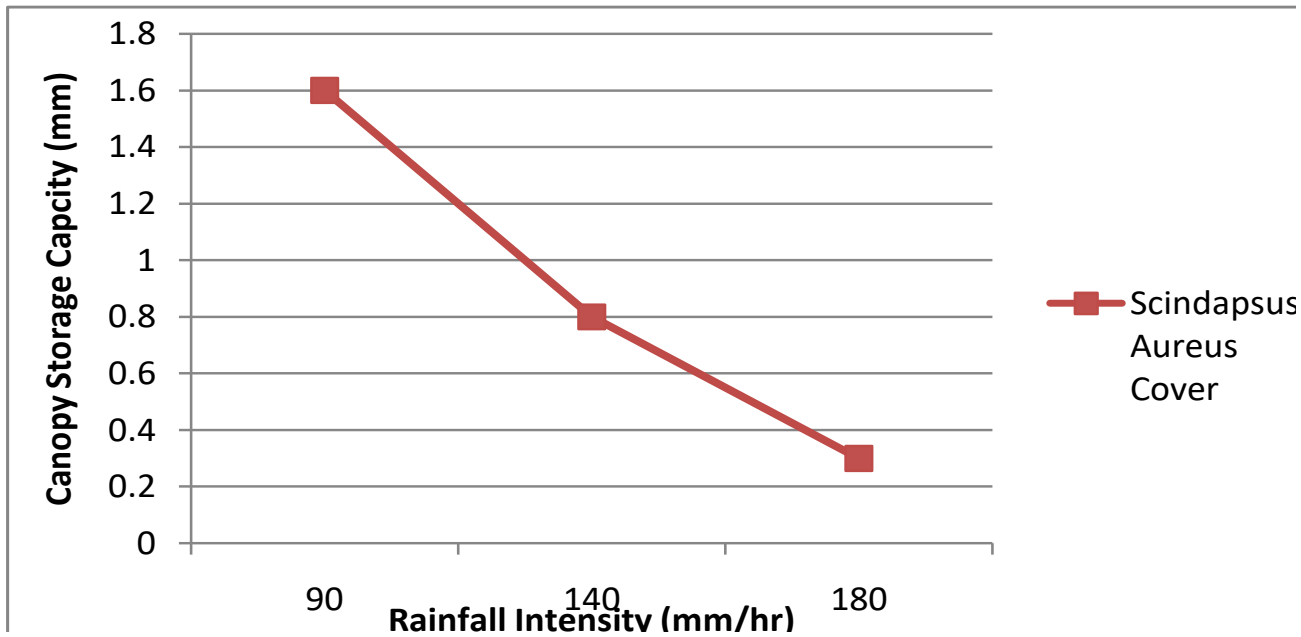

Fig. 6. Relationship between rainfall intensity and canopy storage capacity.

\section{Conclusion}

A rainfall simulator was used for measurement of canopy interception for Scindapsus Aureus. Three different intensities; $90 \mathrm{~mm} / \mathrm{hr}, 140 \mathrm{~mm} / \mathrm{hr}, 180 \mathrm{~mm} / \mathrm{hr}$ were used to investigated the effect of different rainfall intensity on canopy storage capacity. By studying the differences in water storage in barren land and land with canopy cover, the canopy storage capacity was determined. It was found that the canopy storage capacity for Scindapsus Aureus varies with rainfall intensity. Canopy storage capacity was $1.6 \mathrm{~mm}, 0.8$ $\mathrm{mm}$ and $0.3 \mathrm{~mm}$ for $90 \mathrm{~mm} / \mathrm{hr}, 140 \mathrm{~mm} / \mathrm{hr}$ and $180 \mathrm{~mm} / \mathrm{hr}$ rainfall intensity respectively. From the result, it can be concluded that the canopy storage capacity decreases as the rainfall intensity increases.

The authors would like to thank the Ministry of Higher Education (MoHE) for providing research grant File No. 600-RMI/FRGS 5/3 (18/2015).

\section{References}

1. C.T. Tsiko, H. Makurira, A.M.J. Gerrits, H.H.G. Savenije. Measuring Forest Floor and Canopy Interception in Savannah Ecosystem. Phy \& Chemistry of the Earth (47-48), 122-127. (2012)

2. C.B. Zou, G.L. Caterina, R.E. Will, E. Stebler, D. Turton. Canopy Interception for a Tallgrass Prairie under Juniper Encroahment. Plos One (10), 1-19. (2015)

3. H.H. Bulcock, and G.P.W. Jewitt. Spatial Mapping of Leaf Area Index Using Hyperspectral Remote Sensing for Hydrological Applications with a Particular Focus on Canopy Interception. Hyd \& Earth Sys Sci (14), 383-392. (2010)

4. F. André, J. Mathieu, Q. Ponette. Precipitation Water Storage Capacity in a Temperate Mixed Oak-beech Canopy.Hydrol Process (22), 4130-4141 (2008)

5. T. Kume, O.J. Manfori, I.K. Kuraj, N. Tanaka, T. Horiuchi, M. Suzuki, T. Kumagai. Estimation of Water Canopy Storage Capacity from Sap Flow Measurements in a Bornean Tropical Rainforest. J Hydrol (352),288-295. (2008) 
6. C. Véliz-Chávez, C.A. Mastachi-Loza, E. González-Sosa, R. Becerril-Piña, N.M. Ramos-Salinas. Canopy Storage Implications on Interception Loss Modeling. American J of Plant Sci (5), 3032-3048. (2014)

7. O. Fathizadeh, P. Attarod, T.G. Pypker, A.A Darvishsefat, G. Zahedi Amiri. Seasonal Variability of Rainfall Interception and Canopy Storage Capacity Measured under Individual Oak (Quercus brantii) Trees in Western Iran. J. of Agr Sci \& Tech (15), 175-188. (2013)

8. P. Attarod, S.M.M. Sadeghi, T.G. Pypker, H. Bagheri, M. Bagheri, V. Bayramzadeh. Needle-Leaved Trees Impacts on Rainfall Interception and Canopy Storage Capacity in an Arid Environment. New Forest (46), 339-355. (2014)

9. Y. Zulkifli, S.Y. Cham, J.H. Chong. Throughfall, Stemflow and Interception Loss of Old Rubber Trees. J. Cvl. Eng.. 24-33. (2003)

10. Singh C.V. (2017, November 5). Money Plant (Scindapsus aureus) Benefits: Myth or Reality Retrieved from https://dengarden.com

11. British Standard, Methods of Test for Soils for Civil Engineering Purposes. BS 1377

12. Kholler GHE20 Hydrology Apparatus Operation Manual

13. R.F. Keim, A.E. Skaugset, M. Weiler, M. Storage of Water on Vegetation under Simulated Rainfall of Varying Intensity. Adv of W. Resource (26), 974-986. (2006)

14. Y. Schindler Wildhaber, D. Bänninger, K. Burri, C.H. Alewell. Evaluation and Application of a Portable Rainfall Simulator on Subalpine Grassland. Catena (91), 5662. (2012)

15. C. Mayerhofer, G. Meißl, K. Klebinder, B. Kohl, G. Markart. Comparison of The Results of a Small-Plot and a Large-Plot Rainfall Simulator - Effects of Land Use and Land Cover on Surface Runoff in Alpine Catchments. Catena (156), 184-196. (2017)

16. A.M.J. Gerrits. The Role of Interception in the Hydrological Cycle (Doctoral Thesis). Retrieved from uuid:7dd2523b-2169-4e7e-992c-365d2294d02e (2010)

17. Q. Xiao, E.G. McPherson, L. Ustin, M. Grismer, J. Simpson. Winter Rainfall Interception by Two Mature Open-Grown Trees In Davis, California. Hydro Processes (14), 763-784. (2000)

18. H.T.T. Hanh. Using GIS and SWAT model to Assess Soil and Water Resource in Upstream Srepok Watershed, Dak Lak Province (Master's thesis). (2010)

19. N.T.N. Quyen, N.D. Liem, N.K. Loi . Effect of Land Use Change on Water Discharge In Srepok Watershed, Central Highland, Viet Nam. International Soil and Water Conservation Research (2), 74-86. (2014)

20. F.F Zhao, L. Zhang, Z.X. Xu. Effects of Vegetation Cover Change on Streamflow at a Range of Spatial Scales. 18th World IMACS/MODSIM Congress. 3591-3597. (2009)

21. X. Xu, K. Zhang, Y. Kong, J. Chen, B. Yu. Effectiveness Of Erosion Control Measures Along The Qinghai-Tibet Plateau Highway, Tibetan Plateau, China. Transportation Research, Part D: Transport and Environ., (11),302-309. (2006)

22. A. Wang, Y. Diao, T. Pei, C. Jin., J. Zhu. A Semi-Theoretical Model of Canopy Rainfall Interception for a Broadleaved Tree. Hydro Processes 21 (18), 2458- 2463. (2007) 